\title{
Multiplex PCR followed by restriction length polymorphism analysis for the subtyping of bovine herpesvirus 5 isolates
}

\author{
Silvina Soledad Maidana ${ }^{1,2}$, Cintia Débora Morano ${ }^{1}$, Daniela Cianfrini ${ }^{4}$, Fabrício Souza Campos ${ }^{5}$, \\ Paulo Michel Roehe ${ }^{5}$, Bianca Siedler ${ }^{6}$, Gabriel De Stefano ${ }^{1}$, Axel Mauroy ${ }^{7}$, Etienne Thiry ${ }^{7^{*}}$ \\ and Sonia Alejandra Romera ${ }^{1,2,3}$
}

\begin{abstract}
Background: Several types and subtypes of bovine herpesviruses 1 and 5 (BoHV-1 and BoHV-5) have been associated to different clinical conditions of cattle, making type/subtype differentiation essential to understand the pathogenesis and epidemiology of BoHV infections. BoHV-5 subtyping is currently carried out by BstEll restriction enzyme analysis (REA) of the complete virus genome. This method allowed the description of three subtypes, one of which is the most widespread while the remaining two have so far only been found in South America. The present work describes a multiplex PCR followed by REA for BoHV-5 subtyping.

Results: The method consists in the simultaneous amplification of glycoprotein B and UL54 gene fragments of 534 and 669 base pairs (bp), respectively, BstEll digestion of amplicons, separation of products in 1\% agarose gels, and analysis of fragment length polymorphims. The multiplex PCR detected up to 227 BoHV-5 genome copies and $9.2 \times 10^{5}$ BoHV-5 genome copies when DNA was extracted from purified virus or infected tissue homogenates, respectively. The applicability of multiplex PCR-REA was demonstrated on 3 BoHV-5 reference strains. In addition, subtyping of two new isolates and seventeen previously reported ones ( $17 \mathrm{BHV}-5 \mathrm{a}$ and $2 \mathrm{BHV}-5 \mathrm{~b}$ ) by this method gave coincident results with those obtained with the classic BstEll REA assay.
\end{abstract}

Conclusions: Multiplex PCR-REA provides a new tool for the fast and simple diagnosis and subtyping of BoHV-5.

\section{Background}

Bovine herpesvirus 5 (BoHV-5) is an alphaherpesvirus responsible for meningoencephalitis in young cattle, and is antigenically and genetically closely related to bovine herpesvirus 1 (BoHV-1) [1]. The origin and geographic distribution of BoHV-5 infections are largely unknown, mainly due to serological cross-reactivity with BoHV-1 [2]. Sporadic cases of meningoencephalitis by BoHV-5 have been reported in Australia [3], USA [4], Italy [5] and Hungary [6]. In contrast, BoHV-5 infection and disease appear to be more frequent in Argentina and Brazil, where numerous outbreaks were described in the last decades [7-11]. The rare occurrence of BoHV-5 neurological disease in areas

\footnotetext{
*Correspondence: etienne.thiry@ulg.ac.be

${ }^{7}$ Veterinary Virology and Animal Viral Diseases, Department of Infectious and Parasitic Diseases Faculty of Veterinary Medicine, University of Liège, Liège, Belgium

Full list of author information is available at the end of the article
}

where BoHV-1 infection is endemic may be explained by cross-protection induced by natural infection or vaccination [12-14].

BoHV-5 infection induces either a subclinical infection or disease of moderate severity in adult cattle [15] and lethal encephalitis in young animals $[6,7,16]$.

Virological assays are very accurate tools to specifically diagnose BoHV-5 infections. Virus isolation in cell culture can be performed from fresh or frozen nasal secretions, semen or post mortem samples [1]. However, in light of recent reports of bovine herpesviruses isolated from different samples, and responsible for both symptomatic and asymptomatic infections [11,17,18], classical diagnostic methods are not sufficient for a fast and easy identification and subtyping of the infectious virus.

Several assays are available to differentiate BoHV-5 from BoHV-1, including immunoassays using monoclonal antibodies [19-21], PCR followed by REA [22], nested PCR 
[13], multiplex PCR [23-25], random amplified polymorphic DNA (RAPD) [26], and multiple PCR sequencing assays [27]. Moreover, BstEII restriction enzyme analysis (REA) of the complete virus genome can differentiate between BoHV-5 subtypes; but the technique is laborious and needs substantial amounts and quality of viral DNA $[28,29]$. In addition, a recently described UL27PCR-REA [11] assay has been shown to differentiate between BoHV5 subtypes a and b but it cannot differentiate the subtype c.

We here describe a molecular technique that allows the detection and differentiation of all BoHV-5 subtypes. We also report the identification and characterization of two new BoHV-5 isolates from the Argentinean Provinces of Buenos Aires and Chaco. One of them corresponds to a symptomatic case obtained during an outbreak of neurological disease in a cattle herd, while the other corresponds to a non symptomatic case isolated from a bovine semen sample.

This development could be epidemiologically relevant in areas where BoHV-5 infection is endemic, and provides a new tool for the fast diagnosis and subtyping of BoHV-5.

\section{Results}

\section{Differential PCR for BoHV1 and BoHV5}

The new virus isolates 674 and 2010 were tested by multiplex PCR [24] and shown to be BoHV-5.

\section{REA}

One of the new field isolates (2010) showed a BstEII REA pattern similar to reference strain N569, which is the BoHV5 a prototype, and the other (674) showed a pattern similar to reference strain A663, the BoHV-5b prototype (Figure 1). A double $3 \mathrm{~kb}$ band was observed in the first case, but it fell outside of the area used for subtype classification.

\section{Determination of a differential restriction site for a and $c$ subtypes}

Fragments (500 bp) of the UL54 gene from BoHV-5 subtypes a (N569), b (A663 reference strain) and c (ISO97/89) were sequenced. Sequence alignment revealed a point mutation ( $G$ to $A$ ) in the BstEII restriction site for subtype c (1879 nt position, NC_005261.2), as compared to subtype a, responsible for the variation in the REA pattern (Figure 2). This point mutation did not result in an amino acid change.

\section{Multiplex UL27/UL54 PCR and BstEII restriction analysis}

In the new assay developed in this work, the differential expected band pattern for each of the three BoHV-5 subtypes after multiplex PCR-REA is shown in Figure 3. The PCR products after digestion showed different cleaved combinations. The band of $669 \mathrm{bp}$ is cleaved into two bands of 408 and $248 \mathrm{bp}$. Moreover the band of $534 \mathrm{bp}$ is cleaved into two bands of 382 and $152 \mathrm{bp}$. Isolates 674 and 2010 showed band patterns similar to BoHV-5b and BoHV-5a

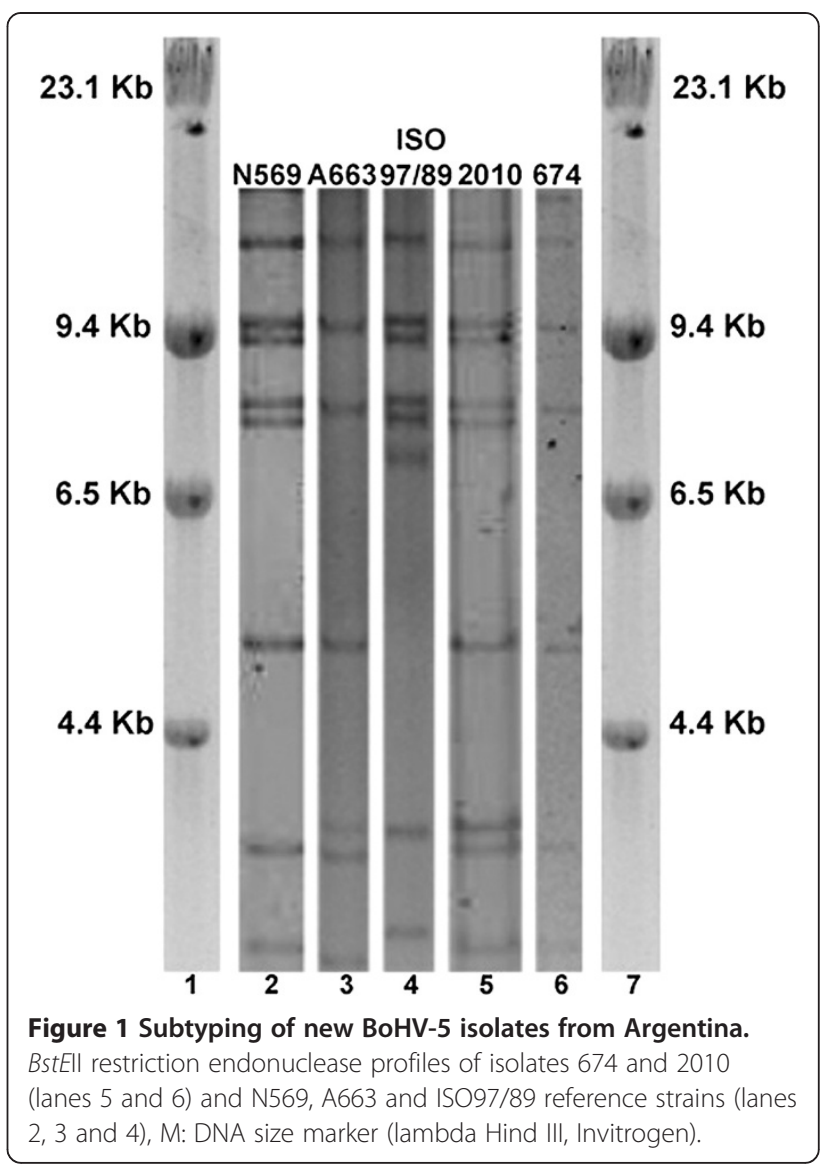

prototypes, respectively (Figure 4). In addition, when DNA of the three different BoHV-1 subtypes was used as template, amplification products could not be digested by BstEII (data not shown).

\section{Sensitivity of the test}

The multiplex PCR assay detected as few as 305 to 455 $\mathrm{ng} / \mu \mathrm{l}$ of purified BoHV-5 DNA or approximately 203 to 303 genome copies. In the case of DNA extracted from infected tissue homogenates the assay detected down to 9.200 genome copies.

\section{Discussion}

In countries like Argentina and Brazil where circulation of BoHV-5 is high and viral subtypes not described elsewhere in the world occur, there is a need for rapid and easy diagnostic tools which allow the classification of viral species and subtypes. In this work, a new multiplex PCR-REA that easily identifies all BoHV-5 subtypes was developed and improves previous assay reported by Claus [24]. The latter can be used as a confirmatory test for the detection of this virus and only allows species differentiation between BoHV-1 and BoHV-5, while our multiplex PCR - REA permits simultaneous subtyping of the isolates. This method was applied to 17 previously characterized virus isolates [11] and 2 newly 


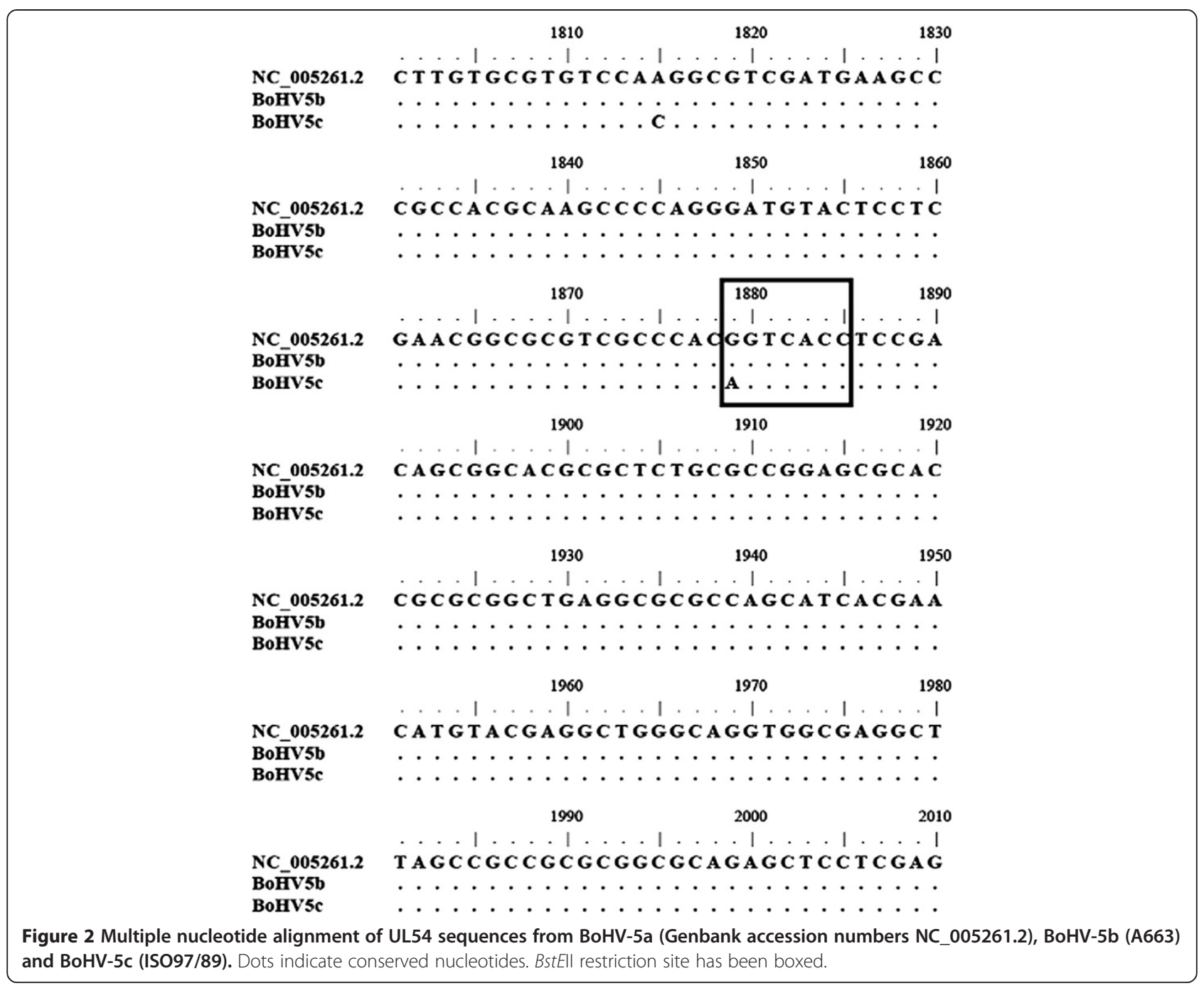

UNDIGESTED
FCR PRODUCTS
Figure $\mathbf{3}$ Scheme expected restrictions patterns with BstEll of multiplex PCR product of BoHV-5 subtypes M: molecular weight marker.
one are digested in subtypes $\mathbf{a}, \mathbf{b}$ and $\mathbf{c}$ respectively.




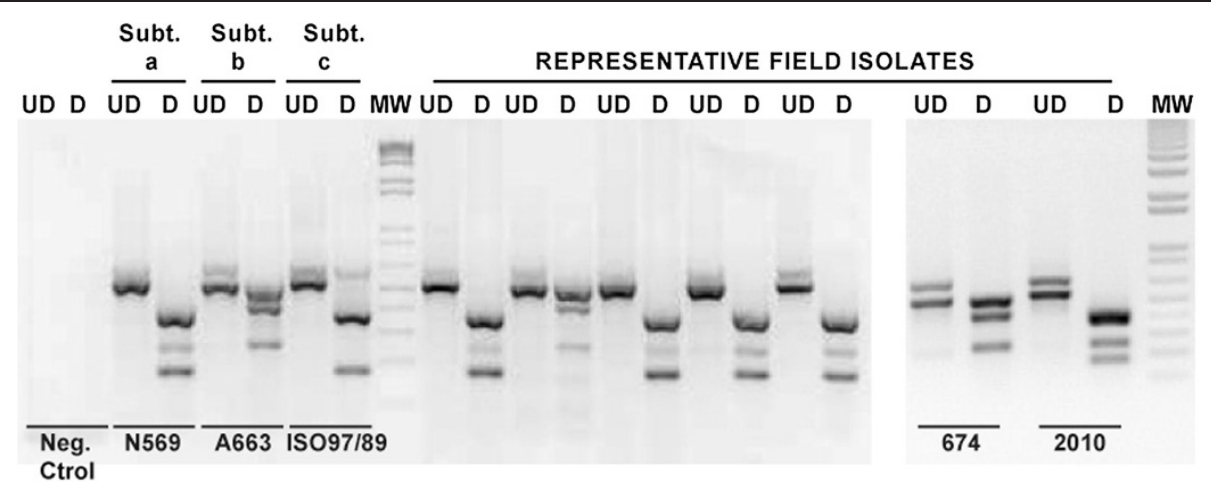

Figure 4 Multiplex PCR-REA applied PCR amplicons before and after digestion with BstEll restrictions enzyme of the Argentine BoHV-5 representative isolates and reference strains. The lanes corresponding to the most recent isolates are marked. Ud: undigested; D: digested; Subt: subtype; Neg.: Control Negative; Ref: reference strain. M: 1 Kb plus DNA size marker.

identified ones. Results were identical to those obtained with the classical BoHV-5 subtyping technique (BstEII restriction profile of the entire genome). When different BoHV-1 subtypes were used as template for this multiplex PCR-REA, fragments of different molecular weight, as compared to BoHV-5, were obtained. Multiplex PCR-REA is more sensitive, faster, less laborious and more economical than the traditional whole genome restriction analysis, and can detect DNA both from purified virus and tissues.

The protocol uses two pairs of primers for the simultaneous amplification of UL27 and UL54 segments. Due to the molecular weight differences in the amplified fragments after digestion, it is possible to clearly distinguish the characteristic bands of each subtype by visual analysis of agarose gels. Amplicon sequencing allowed to find the point mutation responsible for the change on the restriction site of the enzyme BstEII and thus, for the different profiles obtained for a and c subtypes (G-1879 nt-A genbank accession number: NC_005261.2). This mutation was, until now, only observed in subtype c (ISO97/89) strain, isolated in Brazil [29]. We showed here the analysis of one out of two BoHV-5c subtypes reported until now in the world.

The method showed a detection sensitivity of 227 BoHV-5 genome copies of purified virus and $9.2 \times 10^{5}$ BoHV-5 genome copies from tissue samples.

Nineteen BoHV-5 field isolates, including two newly identified ones, were subtyped using the described method. One of the two new isolates included in this work was isolated from cryopreserved bovine semen. To our knowledge, this is the first report of BoHV-5 virus identification from semen in Argentina. This sample was classified as subtype b by multiplex PCR-REA, constituting the last and one of the three BoHV-5b isolates characterized so far. Although no virulence differences between a and b subtypes have been found [30], subtype identification is relevant to understand virus genetic variability and contribute to molecular epidemiology studies. Noteworthy, the virally contaminated semen was harvested from an apparently healthy bull. This finding agrees with similar results obtained in Brazil and Australia $[17,18]$. Whether BoHV-5 transmitted to a cow via artificial insemination (AI) can cause neurological disorders in the recipient remains to be determined. Given the widespread use of AI to diversify cattle stocks, detection of animal viruses in semen, either by virus isolation or PCR, is crucial. In conclusion, the multiplex PCR-REA described in this work provides a new tool for the fast diagnosis and subtyping of BoHV-5. This development can aid in the understanding and control of these detrimental bovine viral infections.

\section{Conclusion}

Fast and easy tools for the characterization of BoHV-5 viral isolates are required. Since, due to technical limitations, sequencing is not an option, the multiplex PCR - REA system described in this work provides an attractive tool for the improved control of BoHV-5 viral infections.

\section{Methods}

\section{Cell culture and virus isolates}

During a routine health test, a BoHV-5-positive semen sample was obtained in 2010 from a clinically healthy bovine from the Argentinean Province of Chaco (isolate 674). The semen sample was diluted 1:6 in fetal calf serum (FCS) and inoculated onto bovine testis cells in minimal essential medium (MEM) containing 10\% FCS. Cells were incubated at $37^{\circ} \mathrm{C}$ in a $5 \% \mathrm{CO}_{2}$ atmosphere, and daily checked for cytopathic effects (CPE). The second characterized isolate was obtained from an animal of about 4 months of age at weaning stage from the Argentine Province of Buenos Aires isolated in 2010 (isolate 2010). A typical outbreak with nervous symptoms and $20 \%$ lethality occurred in the 50-catle herd to which this calf belonged. One gram of brain tissue of this animal was homogenized, suspended in MEM containing $10 \%$ FCS and clarified at $11000 \times g$ for $20 \mathrm{~min}$ at $4^{\circ} \mathrm{C}$. Then, half of the supernatant was inoculated into bovine testis cells in MEM containing 10\% FCS 
and the other half was used for DNA extraction. Isolates 674 and 2010 originated therefore from samples sent to diagnostic laboratories for routine testing and are not subjected to a prior approval by the animal welfare committee. Three BoHV-5 reference strains were used as subtype controls: N569 (BoHV-5a), A663 (BoHV-5b) and ISO 97/87 (BoHV-5c). After standardization of the multiplex PCR assay, the method was tested on the two new isolates mentioned above and 17 previously characterized BoHV-5 (16 BoHV-5a and 1 BoHV-5b) field isolates [11].

\section{DNA extraction for PCR}

The infected cell culture supernatant from semen and the supernatant of homogenized tissue of the BoHV-5 positive sample were subjected to DNA extraction using QIAamp DNA Mini kit (Qiagen, Hilden, Germany) according to the manufacturer's protocol. Purified DNA was stored at $20^{\circ} \mathrm{C}$ until testing. DNA concentration was deduced from absorbance measured in a spectrophotometer.

\section{Differential PCR for BoHV-1 and BoHV-5}

To identify the viral species of isolates 674 and 2010, the multiplex PCR designed by Claus and collaborators [24] was carried out. Amplification products were of $354 \mathrm{bp}$ and 159 bp for BoHV-1 and BoHV-5, respectively. Products were analyzed on $1 \%$ agarose gel electrophoresis, stained with ethidium bromide $(0.5 \mu \mathrm{g} / \mathrm{ml})$ in TBE buffer $(89 \mathrm{mM}$ Tris, $89 \mathrm{mM}$ boric acid, $2 \mathrm{mM}$ EDTA, pH8.4), and visualized under UV light.

\section{Classic subtyping of BoHV-5 by restriction endonuclease analysis (REA)}

Field isolates 674 and 2010 were inoculated in tissue culture flaks $\left(175 \mathrm{~cm}^{2}\right)$ with nearly confluent, overnight grown MDBK (Madin Darby bovine kidney) monolayers, at a multiplicity of infection of 0.1 , and incubated at $37^{\circ} \mathrm{C}$ and $5 \% \mathrm{CO}_{2}$. Post infection cultures were frozen at $-80^{\circ} \mathrm{C}$. After two successive rounds of freezing and thawing, clarification was carried out at $3000 \mathrm{rpm}$ for $20 \mathrm{~min}$ at $4^{\circ} \mathrm{C}$. Purification and extraction of viral DNA was performed as detailed by Maidana et al. [11].

Four $\mu \mathrm{g}$ of viral DNA from each reference strain and field isolate (2010 and 674) were incubated overnight with BstEII restriction enzyme (1U) under the conditions recommended by the manufacturer (Promega, Wisconsin, USA). Digestion products were separated overnight by electrophoresis on $0.7 \%$ agarose gels at $50 \mathrm{~V}$ using TBE buffer. Gels were stained with ethidium bromide and photographed under UV light.

\section{Identification of differential restriction sites between subtype a and c}

Although differential PCRs to discriminate between BoHV1 and BoHV-5, or between BoHV5a and b subtypes have been developed [11,24], subtype c is still indistinguishable by these techniques. In silico analysis showed that a site included in the open reading frame of the UL54 gene serves to differentiate subtype $\mathrm{c}$ from the other two. Primers were designed based on the published sequence of BoHV-5 (Genbank accession number: NC_005261.2) (UL54F: TATAAC-CCC-CTC-AAC-AAA-AT (nt 1631 to 1650) and UL54R: TCT-GCG-AGT-ACC-AGG-TGC-CG nt 2280 to 2300). DNA sequence analysis to locate polymorphic regions within the UL54 target gene was performed using Vector NTI Suite version 8.0 (Invitrogen, Merelbeke, Belgium).

The assay was performed with purified DNA from strains of different subtypes

Amplification was carried out in a $50 \mu \mathrm{l}$ reaction mix containing $5 \mathrm{ng}$ of template DNA, Taq DNA polymerase buffer (NEB, Ipswich, MA, USA), $2 \mathrm{mM} \mathrm{MgCl}_{2}, 6 \%$ DMSO, $200 \mu \mathrm{M}$ dNTPs, $0.3 \mu \mathrm{M}$ of both forward and reverse primers and $1 \mathrm{U}$ Taq DNA polymerase (NEB). Annealing temperatures were optimized for each primer pair. The PCR program consisted of $10 \mathrm{~min}$ at $96^{\circ} \mathrm{C}$, followed by 35 cycles of $1 \mathrm{~min}$ at $96^{\circ} \mathrm{C} ; 1 \mathrm{~min}$ at $58^{\circ} \mathrm{C}$ and $1 \mathrm{~min}$ at $72^{\circ} \mathrm{C}$ with a final extension step of $10 \mathrm{~min}$ at $72^{\circ} \mathrm{C}$. The resulting products were separated by electrophoresis in 1\% agarose gels and visualized under UV light after ethidium bromide staining. Amplified products were purified using Illustra GFX ${ }^{\mathrm{mm}}$ PCR, DNA and gel band purification kit (GE Healthcare, Diegem, Belgium). The quality of all DNA preparations was evaluated by agarose gel electrophoresis. Sequencing reactions were performed with BigDye Terminator v3.0 kit (Applied Biosystems, Lennik, Belgium) and analyzed in an ABI Prism 3730 DNA Analyzer (Applied Biosystems).

Each PCR product of reference strains was sequenced twice in both directions using forward and reverse primers. Nucleotide and predicted amino acid sequences were edited; aligned and analyzed with BioEdit version 7.0.5.3 [31] to determine single nucleotide polymorphisms at BstEII restriction sites.

\section{Multiplex PCR-REA assay for BoHV-5 subtyping}

UL27 PCR assay [11] was modified for easy discrimination between three BoHV-5 subtypes. The above described UL54 primers that amplify a fragment of 669 bp were incorporated into the UL27 PCR [11]. As template, total genomic material of the three subtypes of BoHV-5 was used. The expected results of this multiplex PCR are two bands of $669 \mathrm{bp}$ and $534 \mathrm{bp}$, respectively. The reaction mix with two pair primers (UL54F-UL54R, UL27F-UL27R) and the PCR program used were the same as described above.

Aliquots $(25 \mu \mathrm{l})$ of the PCR products were incubated with $B s t E I I$, while the remaining $25 \mu \mathrm{l}$ were used as undigested control. The resulting products were separated by electrophoresis in $1 \%$ agarose gels and visualized under UV light 
after ethidium bromide staining. The pattern of expected products before and after digestion is shown in Figure 3.

The applicability of multiplex PCR-REA was demonstrated on reference strains corresponding to the 3 different subtypes of each BoHV-5 as well as on 17 previously characterized BoHV-5 fields isolates [11].

\section{Sensitivity of the test}

To evaluate the sensitivity of the multiplex PCR, 10-fold serial dilutions of DNA obtained from different types of samples (purified virus and infected tissue homogenates) were used as template. Then copy numbers were calculated based on mass estimations of the entire genome of BoHV-5 mass and of the DNA samples analyzed.

\section{Competing interests}

The authors declare that there are no competing interests.

\section{Authors' contributions}

SM and SR designed the experiments, analyzed the data and drafted the manuscript together. SM performed the experiments. FC, PR and BS kindly provided the reference strains. ET and AM participated in the interpretation of data and preparation of the manuscript draft. CM, DC and GD helped with virus amplification on cell cultures. All authors read and approved the final manuscript.

\section{Acknowledgments}

The authors wish to thank Mónica Florin-Christensen (INTA) and María Isabel Craig (INTA) for revising the manuscript and Matías Ottaviani for help in the figures design. This work was supported by Fonds de la Recherche Scientifique (FRS-FNRS, Belgium) and CONICET (Argentina). SM is a CONICET fellow.

${ }^{1}$ Etienne Thiry and Sonia Alejandra Romera are co-last authors.

\section{Author details}

${ }^{1}$ Instituto de Virología, Centro de Investigaciones en Ciencias Veterinarias y, Agronómicas (CICVyA), Instituto de tecnología Agropecuaria (INTA), N. Repetto, y Los Reseros S/N, CC25, (B1712WAA), Castelar, Buenos Aires, Argentina. ${ }^{2}$ Consejo Nacional de Investigaciones, Científicas y Tecnológicas (CONICET), Rivadavia 1917, (C1033AAJ), Ciudad Autónoma de Buenos Aires, Argentina. ${ }^{3}$ Inmunología, Universidad del Salvador, Champagnat 1599-Ruta Panamericana-Km 54.5 Pilar, -B1630AHU-Provincia de Buenos Aires, Argentina. ${ }^{4}$ Tecnovax SA, Luis Viale 2835, 1416, Ciudad Autónoma de Buenos Aires, Argentina. ${ }^{5}$ Virology Laboratory, Department of Microbiology, Immunology and Parasitology, Institute of Basic Health Sciences, Federal University of Rio Grande do Sul (UFRGS), Av. Sarmento Leite 500, Porto Alegre 90050-170, Rio Grande do Sul (RS), Brazil. ' 'Laboratório de Bioprocessos, Universidade Federal de Pelotas, Rua Gomes Carneiro, 1, 96010-610, Pelotas, Brasil. Veterinary Virology and Animal Viral Diseases, Department of Infectious and Parasitic Diseases Faculty of Veterinary Medicine, University of Liège, Liège, Belgium.

Received: 21 January 2013 Accepted: 1 June 2013

Published: 4 June 2013

\section{Reference}

1. Del Medico Zajac MP, Ladelfa MF, Kotsias F, Muylkens B, Thiry J, Thiry E, Romera SA: Biology of bovine herpesvirus 5. Vet J 2010, 184:138-145.

2. Vogel FS, Caron L, Flores EF, Weiblen R, Winkelmann ER, Mayer SV, Bastos RG: Distribution of bovine herpesvirus type 5 DNA in the central nervous systems of latently, experimentally infected calves. J Clin Microbiol 2003, 41:4512-4520.

3. French EL: A specific virus encephalitis in calves: isolation and characterization of the causal agent. Aust Vet J 1962, 38:216-221.

4. D'Offay JM, Mock RE, Fulton RW: Isolation and characterization of encephalitic bovine herpesvirus type 1 isolates from cattle in North America. Am J Vet Res 1993, 54:534-539.
5. Moretti B, Orfei Z, Mondino G, Persechino A: [Isolation of the Infectious Bovine Rhinotracheitis (lbr) Virus in Italy. (Preliminary Note). Nuovi Ann Ig Microb 1964, 15:18-22.

6. Bartha A, Hajdu G, Aldasy P, Paczolay G: Occurrence of encephalitis caused by infectious bovine rhinotracheitis virus in calves in hungary. Acta Vet Acad Sci Hung 1969, 19:145-151.

7. Carrillo BJ, Ambrogi A, Schudel AA, Vazquez M, Dahme E, Pospischil A: Meningoencephalitis caused by IBR virus in calves in Argentina. Zb/ Vet Med B J Vet Med 1983, 30:327-332.

8. Weiblen R, De Barros CS, Canabarro TF, Flores IE: Bovine meningoencephalitis from IBR virus. Vet Rec 1989, 124:666-667.

9. Roehe PM, Silva TC, Nardi NB, Oliveira LG, Rosa JCA: Differentiation between viruses of infectious bovine rhinotracheitis (BHV-1) and bovine encephalitis herpesvirus (BHV-5) with monoclonal antibodies. Pesq Vet Bras 1997, 17:41-44.

10. Rissi DR, Pierezan F, Silva MS, Flores EF, De Barros CS: Neurological disease in cattle in southern Brazil associated with Bovine herpesvirus infection. J Vet Diagn Invest 2008, 20:346-349.

11. Maidana SS, Ladelfa MF, Perez SE, Lomonaco PM, Del Medico Zajac MP, Odeon A, Blanco Viera J, Combessies G, Fondevila N, Palacios M, et al: Characterization of BoHV-5 field strains circulation and report of transient specific subtype of bovine herpesvirus 5 in Argentina. BMC Vet Res 2011, 7:8.

12. Thiry E, Muylkens B, Meurens F, Gogev S, Thiry J, Vanderplasschen A, Schynts F: Recombination in the alphaherpesvirus bovine herpesvirus 1. Vet Microbiol 2006, 113:171-177.

13. Cascio KE, Belknap EB, Schultheiss PC, Ames AD, Collins JK: Encephalitis induced by bovine herpesvirus 5 and protection by prior vaccination or infection with bovine herpesvirus 1. J Vet Diagn Invest 1999, 11:134-139.

14. Del Medico Zajac MP, Puntel M, Zamorano PI, Sadir AM, Romera SA: BHV-1 vaccine induces cross-protection against BHV-5 disease in cattle. Res Vet Sci 2006, 81:327-334

15. Ashbaugh SE, Thompson KE, Belknap EB, Schultheiss PC, Chowdhury S, Collins JK: Specific detection of shedding and latency of bovine herpesvirus 1 and 5 using a nested polymerase chain reaction. J Vet Diagn Invest 1997, 9:387-394.

16. Meyer G, Lemaire M, Ros C, Belak K, Gabriel A, Cassart D, Coignoul F, Belak S, Thiry E: Comparative pathogenesis of acute and latent infections of calves with bovine herpesvirus types 1 and 5. Arch Virol 2001, 146:633-652.

17. Diallo IS, Corney BG, Rodwell BJ: Detection and differentiation of bovine herpesvirus 1 and 5 using a multiplex real-time polymerase chain reaction. J Virol Methods 2011, 175:46-52.

18. Oliveira MT, Campos FS, Dias MM, Velho FA, Freneau GE, Brito WM, Rijsewijk FA, Franco AC, Roehe PM: Detection of bovine herpesvirus 1 and 5 in semen from Brazilian bulls. Theriogenology 2011, 75:1139-1145.

19. Metzler AE, Matile H, Gassmann U, Engels M, Wyler R: European isolates of bovine herpesvirus 1: a comparison of restriction endonuclease sites, polypeptides, and reactivity with monoclonal antibodies. Arch Virol 1985, 85:57-69.

20. Keuser V, Schynts F, Detry B, Collard A, Robert B, Vanderplasschen A, Pastoret PP, Thiry E: Improved antigenic methods for differential diagnosis of bovine, caprine, and cervine alphaherpesviruses related to bovine herpesvirus 1. J Clin Microbiol 2004, 42:1228-1235.

21. Thiry J, Tempesta M, Camero M, Tarsitano E, Muylkens B, Meurens F, Thiry E, Buonavoglia C: Clinical protection against caprine herpesvirus 1 genital infection by intranasal administration of a live attenuated glycoprotein $\mathrm{E}$ negative bovine herpesvirus 1 vaccine. BMC Vet Res 2007, 3:33.

22. Ros C, Belak S: Studies of genetic relationships between bovine, caprine, cervine, and rangiferine alphaherpesviruses and improved molecular methods for virus detection and identification. J Clin Microbiol 1999, 37:1247-1253.

23. Alegre M, Nanni M, Fondevila N: Development of a multiplex polymerase chain reaction for the differentiation of bovine herpesvirus- 1 and -5 . J Vet Med 2001, 48:613-621.

24. Claus MP, Alfieri AF, Folgueras-Flatschart AV, Wosiacki SR, Medici KC, Alfieri AA: Rapid detection and differentiation of bovine herpesvirus 1 and 5 glycoprotein $\mathrm{C}$ gene in clinical specimens by multiplex-PCR. J Virol Methods 2005, 128:183-188.

25. Thiry J, Widen F, Gregoire F, Linden A, Belak S, Thiry E: Isolation and characterisation of a ruminant alphaherpesvirus closely related to bovine herpesvirus 1 in a free-ranging red deer. BMC Vet Res 2007, 3:26. 
26. Afonso DA, Ortega LS, Redondo RA, Trindade Gde S, Barbosa-Stancioli EF: Characterization of field bovine herpesvirus samples using random amplified polymorphic DNA (RAPD). J Virol Methods 2007, 140:200-205.

27. Del Medico Zajac MP, Romera SA, Ladelfa MF, Kotsias F, Thiry J, Ziant D, Meurens F, Keil GM, Thiry E, Muylkens B: Characterization of interspecific recombinants generated from closely related bovine herpesviruses 1 and 5 through multiple PCR sequencing assays. J Virol Methods 2009, 161:75-83.

28. Brake F, Studdert MJ: Molecular epidemiology and pathogenesis of ruminant herpesviruses including bovine, buffalo and caprine herpesviruses I and bovine encephalitis herpesvirus. Aust Vet J 1985, 62:331-334

29. D'Arce RC, Almeida RS, Silva TC, Franco AC, Spilki F, Roehe PM, Arns CW: Restriction endonuclease and monoclonal antibody analysis of Brazilian isolates of bovine herpesviruses types 1 and 5. Vet Microbiol 2002, 88:315-324.

30. Ladelfa MF, Del Medico Zajac MP, Kotsias F, Delgado F, Muylkens B, Thiry J, Thiry E, Romera SA: Comparative study on the in vitro and in vivo properties of two bovine herpesvirus- 5 reference strains. Acta Vet Scand 2011, 53:37.

31. Hall TA: BioEdit: a user-friendly biological sequence alignment editor and analysis program for Windows 95/98/NT. Nucl Acids Symp Ser 1999, 41:95-98.

\section{doi:10.1186/1746-6148-9-111}

Cite this article as: Maidana et al:: Multiplex PCR followed by restriction length polymorphism analysis for the subtyping of bovine herpesvirus 5 isolates. BMC Veterinary Research 2013 9:111.

\section{Submit your next manuscript to BioMed Central and take full advantage of:}

- Convenient online submission

- Thorough peer review

- No space constraints or color figure charges

- Immediate publication on acceptance

- Inclusion in PubMed, CAS, Scopus and Google Scholar

- Research which is freely available for redistribution 